\title{
INFÂNCIA, CINEMA, LIRISMO: A poética do sonho de Wadjda
}

\author{
Michele de Freitas Faria de Vasconcelos* \\ Rui Benevides Prates** \\ Marcos Ribeiro de Melo***
}

\begin{abstract}
Resumo: Aproximando imagens cinematográficas, poéticas e traquinagens, este artigo procura desestabilizar certezas sobre infância e relações de gênero. Experimentando uma etnografia de tela, nos encontramos com "O sonho de Wadjda", em uma dupla caminhada: acompanhando os passos da meninapersonagem e da diretora do longa-metragem, Haiffa Al Mansour, em suas possibilidades de transver, desdizer, inventar realidades. Enquanto esta subverte seu lugar de mulher-cineasta na cultura androcêntrica/patriarcal árabe, Wadjda, guiada pelo desejo de comprar uma bicicleta verde, põe em xeque as engrenagens religiosa e escolar que limitam seu território existencial. Mansour e Wadja reinventam a própria vida e, assim, nos convidam a embarcar em devires-criança e devires-mulher.
\end{abstract}

Palavras-Chave: infância; gênero; etnografia de tela.

CHILDHOOD, CINEMA, LYRICISM: the Wadjda dream's poetic

\begin{abstract}
Approaching cinematographic images, poetics and tricks, this article seeks to destabilize certainties about childhood and gender relations. Experiencing screen ethnography, we meet "Wadjda", in a double walk: following the steps of the girl-character and the director of the feature film, Haiffa Al Mansour, in their possibilities of to produce new visions, to disdain, to invent realities. While she subverts her place as a woman-filmmaker in Arab/ patriarchal culture, Wadjda, driven by the desire to buy a green bicycle, puts in check the religious and school gears that limit her existential territory. Mansour and Wadja reinvent their own lives and thus invite us to embark on becoming woman and child. Keywords: childhood; gender; screen etnography
\end{abstract}

Submissão 15-10-18 Aceite 14-12-18

\section{DO GEERGE AO BALBUCIOS, DA UFRGS À UFS}

Este artigo para nós é um marco. Produto-marca, primeiro fruto de um ano de pesquisa do grupo Balbucios. Tal escrito consiste em uma sistematização das experimentações em territórios políticos, éticos, estéticos, imagéticos, existenciais que se insinuam num vazar a tela e imiscuir a vida. Trata-se de um texto fiado pela análise de uma infância por meio de um olhar transversalizado pela lente do gênero. Um texto produzido a partir de análises desenvolvidas coletivamente ao longo de um ano de pesquisa com o método da etnografia de tela. Os norteadores teórico-conceituaismetodológicos deste grupo inspiram-se na fonte: o Geerge em sua ousadia de pensar com a lente fílmica e a lente do gênero. $O$ Balbucios traz em sua movimentação as marcas político-afetivas inscritas em nossos corpos por meio das conversas, trocas,

\footnotetext{
* Graduação em Psicologia (UFS); mestrado em Saúde coletiva (ISC/UFBA); doutorado em Educação (UFRGS). Professora Adjunta do Departamento de Psicologia (UFS) e do PPGPSI/UFS.

*** Mestrando em Filosofia (UFBA); Graduação em Psicologia (UFS). Foi bolsista PIBIC do grupo de pesquisa Balbucios (UFS) de 2016 a 2018.

**** Graduação em Psicologia (UFS); mestrado em Saúde coletiva (ISC/UFBA); doutorado em Educação (UFRGS). Professor Adjunto do Departamento de Psicologia (UFS) e do PPGCine/UFS.
} 
aulas, escritos, pesquisas, análises da/com a Guacira Louro, Dagmar Meyer, Fernando Seffner, Patrícia Balestrin, Rosângela Soares, Jeane Felix, Felipe Zago. Do Rio Grande do Sul a Sergipe, distâncias geográficas se desfazem numa política relacional e de aliança, destas que ainda nos fazem apostar na academia e na pesquisa como espaço de ampliação da vida na contramão da produtividade neoliberal. Um brinde ao GEERGE, um brinde ao Balbucios, porque como diria Larrosa (2006), inspirando-se em Hanna Arendt, educação sempre tem a ver com nascimento, com o germinar da vida que balbucia novos sentidos, sentindo.

\section{NOTAS SOBRE UM MÉTODO, UMA (PO)ÉTICA}

Êle está dentro de mim. / Ansioso. Revôlto. Múltiplo. / É pássaro. / Asas
largas. / Quer a pureza das fontes intocadas. / Quer as conchas da praia
que ninguém achou. / Quer a Vida. / Êle está dentro de mim. / O poema . (Firmino Rocha. Canto do dia Nôvo, 1968, p. 11).

Cinema e infância têm "um quê" de lirismo, se cruzam na inventividade. Esse texto se propõe a demorar-se nisto que nos parece uma grande pista para experimentar um ir se desimpregnando de todo um longo histórico de aprendizagens e naturalizações acerca das relações de gênero e da infância como etapa de desenvolvimento rumo à mais alta evolução do mundo adulto generificado. Uma moral de gênero e de faixa etária tende a conformar os corpos de todos/as, qualquer e cada um/a de nós.

Buscou-se - e ainda se busca - uma narratividade, uma desaprendizagem, "um mudar de sentir" (NIETZSCHE, 1978, p. 169), uma experiência de escrita que lance ao descaminho, à invenção, à produção de sentidos. Como diria Jorge Larrosa (2016, p. 25): “Do ponto de vista da experiência, o importante [é] a 'exposição', nossa maneira de 'ex-pormos', com tudo o que isso tem de vulnerabilidade e de risco. Em vez de, com um olhar reflexivo sobre um objeto do cotidiano, no caso deste texto sobre infância, a fim de lhe tirar algumas significações, narramos o que nos passa, nos acontece, nos toca, nos ocorre, nos afeta, nos ameaça. "A experiência é tentar chegar a um certo ponto da vida que seja o mais perto possível do não passível de ser vivido" (FOUCAULT, 2010, p. 291). Assim, podemos dizer que ousamos/alçamos a poesia.

Inspirando-nos na etnografia de tela, mergulhamos na história de uma menina saudita de 10 anos. Pinçamos cenas, observamos e descrevemos enquadramentos, planos, sequências, cenários, iluminação, “os modos de apresentar as personagens e seus movimentos dentro da tela, as escolhas relativas à montagem e ao modo de narrar as histórias" (BALESTRIN e SOARES, 2012, 94) do filme "o Sonho de Wadjda". 
Lançado em 2012, "O Sonho de Wadjda" é um filme saudita que conta um trecho da história de uma pequena garota cujo maior desejo é adquirir uma bicicleta. Trata-se do primeiro longa-metragem completamente rodado na Arábia Saudita, um país onde, por motivos religiosos, desde a década de 1970, não há salas oficiais de cinema $^{1}$. A produção e a direção do trabalho, realizadas por uma mulher, Haiffa Al Mansour, e o enredo da película, apresentam um duplo protagonismo de mulheres muito pouco comum à história daquele país, onde as leis islâmicas limitam os seus direitos civis. As dificuldades para a execução do filme perpassaram não somente a questão financeira, cuja captação de recursos durou cinco anos, mas também a própria atividade de direção. A proibição de homens e mulheres frequentarem espaços comuns em público, por exemplo, gerou mudanças no set de filmagem, pois a diretora não poderia estar junto com sua equipe. Em suas próprias palavras:

Há muitas dificuldades que eu encaro como mulher. As pessoas na Arábia Saudita estão sempre interessadas em te ouvir e aprender muitas coisas. Quando uma mulher está tentando gravar um filme, a história é diferente. Isto é algo bonito, mas há outras, como por exemplo, vocês estavam conosco durante a filmagem, muitas vezes eu não podia sair da van para estar com os atores. Não conseguir vê-los ao vivo e instruí-los é uma grande mudança. Eu tinha que dirigi-los através de um walkie-talkie ou de um assistente de direção. Isso, às vezes, era difícil (MANSOUR, 2015)².

Se encarado inicialmente como um projeto pessoal, pois o filme fala sobre a realidade do local onde Haiffa Al Mansour cresceu, ele também abrange ideias sobre como as pessoas se "distanciam da intolerância, encarando o que há de bom em nós, o trabalho árduo do aceitar 'o outro'. Isto é o que a arte faz quebrando as barreiras dos gêneros e das culturas. Fazendo-nos entender como nós respeitamos uns aos outros, amamos e cuidamos uns dos outros" (MANSOUR, 2015).

De certo modo, Mansour parece convocar uma certa ética, aqui colocada em forma de pergunta: como forjar, ativar, fazer de uma narrativa, ou de uma pesquisa que se compõe por meio de narrativas, um corpo fabulador de mundos? Como construir uma narrativa que possibilite o escamar de

[...] algumas "evidências", ou "lugares-comuns [...] fazer juntamente com muitos outros, de modo que certas frases não possam mais ser ditas tão facilmente, ou que certos gestos não mais sejam feitos sem,

\footnotetext{
${ }^{1}$ Uma incipiente tentativa de abertura do cenário cultural tem sofrido duras críticas das autoridades religiosas que consideram o cinema como porta para a entrada de filmes estrangeiros "ateístas" ou de encorajamento de mistura entre os sexos (Folha de São Paulo, Ilustrada, 15/01/2017).

2 Trecho de uma entrevista da diretora disponível em https://www.youtube.com/watch?v=q3q05VLc6u4. Acesso em 20 de jan. 2017 (tradução livre da/os autora/es).
} 
pelo menos, alguma hesitação; contribuir para que algumas coisas mudem nos modos de perceber e nas maneiras de fazer; participar desse difícil deslocamento das formas de sensibilidade e dos umbrais de tolerância (FOUCAULT, 2006, p. 347).

Essa político-ética da narratividade nos convoca a inverter os quadros do que costumamos pensar quando evocamos os termos respeito e tolerância, uma atitude que pede, como diria Nietzsche, desaprendizagens e, talvez, um esforço maior ainda: deslocar as formas de sensibilidade, mudar de sentir. Eis nossa aposta numa pesquisa e numa narrativa que se tece por entre ciência e cinema: o cinema, ou pelo menos algumas imagens cinematográficas, trazem consigo a força de afetação, de resistir ao intolerável, de estranhar o que é posto como intolerável (LOURO, 2004).

Eis o que almejamos com o empreendimento desta escrita: posicionarmo-nos na contramão de posturas politicamente corretas que solicitam a tolerância e o respeito ao discrepante, ao 'excêntrico', desde que a possibilidade deste excêntrico hibridizar seja barrada, desde que seja identificado e normalizado. Ao contrário, resistir à sede de formas e identidades que toma nossos corpos "toxicômanos de identidade" (ROLNIK, 1997), "afetar, deixar-se afetar, voltar a acreditar no mundo, [...] resistir ao intolerável" (PELBART, 2003, p. 55). Com o corpo da pesquisa, estranhar o que é posto como intolerável (LOURO, 2004), aquilo que Renè Lourau (1995) denomina de interferência: produzir uma perturbação no que parece óbvio, no que aparece na cena instituída como não passível de se tolerar. A partir desse posicionamento, intolerável passa a não dizer respeito ao que a maioria das pessoas acha que é. Ao contrário, vestígios do intolerável parecem se localizar justamente no que para muita gente não o é, e sim 'normal', colocado no plano do aceitável.

A tolerância e o respeito a que o Sonho de Wadja nos convoca, conspira um exercício ético que emerge justamente dessa sensibilidade ao intolerável. E é intolerável que um corpo seja alijado de sua potência para caber em fôrmas político-culturais-institucionais-subjetivas; é intolerável que vidas humanas sejam organizadas e que, nessa organização, suas intensidades sejam reduzidas a morais, arrimos do instituído (PAULON, 2006), de gênero e faixa-etárias e tantas outras para caberem em quadros de referências modelizantes. Acompanhar a vida ali onde ela não se deixa nominar, eis a força de nosso agenciamento com o cinema de Mansour: fabular vidas, pois tudo que não inventamos é falso (BARROS, 1997). 


\section{'O SONHO QUE SONHEI É OUTRO, A VIDA QUE CRIEI É MINHA3’’}

Com sua mochila jeans nas costas e sobre seu velho e inseparável 'All star', Wadjda segue seu caminho diário até a escola. Em seu trajeto, brinca de arremessar ao ar uma "pedra vulcânica" do belo e perigoso deserto de Rub' al Khali, um presente do pai que não via há uma semana. Logo encontra seu amigo, Abdullah. Entre sorrisos e brincadeiras, Abdullah pega um sanduíche matinal que Wadjda também carregava nas mãos. As duas crianças correm pelas calçadas da grande cidade. Wadja alcança Abdullah e exclama em tom de vitória: - Peguei meu sanduíche de volta! A câmera segue um emudecido Abdullah que corre em direção contrária à da garota. Wadjda continua seu caminho, mas vemos uma mão puxar o véu negro que cobre seus cabelos. É Abdullah que retorna guiando uma bicicleta. Desequilibrada pelo puxão, Wadjda deixa cair o sanduíche e, num tom desafiador o menino indaga: - Você acha mesmo que podia me alcançar? Silenciosamente, a garota saudita retoma seu caminho. Segura por certa distância que mantém dos garotos aos quais Abdullah se junta, Wadja argumenta em tom de ameaça: - Se eu tivesse bicicleta, você ia ver.

Avista-se a escola 'para meninas' em que Wadjda estuda. Ouvimos risadas e, em seguida, a imagem de duas garotas chegando ao prédio escolar. Imediatamente a isto, as risadas são interrompidas pelas cortantes palavras da diretora, a Sra. Hussa, que adverte: - Meninas parem. Por que estão rindo alto? A voz da mulher não deve ser ouvida pelos homens lá fora. [...]. A voz da mulher é a nudez dela. Em seguida, com a câmera baixa, reconhecemos o tênis de Wadjda que, ao chegar, também é admoestada: - Wadjda! Onde está o seu lenço? Você veio sem cobrir a cabeça? O sisudo rosto de Wadjda, ao ouvir as reclamações da Sra. Hussa, logo esboça um sorriso com as risadas das outras meninas que, apesar da presença da diretora, não se contém diante da transgressão da colega de escola. O sinal da escola toca. Num plano mais aberto, observa-se a sua fachada. A leveza da parede pintada em tom arenoso contrasta com as grades quadriculadas que remetem a uma prisão. A gigantesca porta de madeira se fecha. As aulas irão começar.

$\mathrm{O}$ enquadramento da câmera apresenta uma imagem aberta. Uma casa em construção e um terreno baldio são o cenário. Wadjda retorna da escola. Um dos pedreiros grita para a menina: - Vem aqui brincar com a gente. Quero tocar essas maçãzinhas. Em meio ao deboche o homem continua: - Vem. Vem. A pequena garota

\footnotetext{
${ }^{3}$ Polayne (2009).
} 
não se intimida. Com olhar fixo, encara aquele que a agride. A câmera novamente se distancia. Vê-se Abdullah chegar. Wadjda diz que não quer falar com o amigo. A câmera volta a se distanciar das duas crianças. Agora a ventania espalha a areia do deserto pelas ruas. Numa tentativa de se desculpar pelo ocorrido mais cedo, Abdullah entrega-lhe um presente. Wadjda parece não estar disposta a perdoar-lhe e diz: - Ainda não ficamos quites. Quando eu tiver bicicleta, ganho a corrida e aí sim! Relembrando o lugar social da amiga e das mulheres, Abdullah a adverte: - Você sabe que meninas não andam de bicicleta? E em tom jocoso Wadjda responde: - Perder para uma menina vai ser derrota em dobro. Wadjda retoma o seu caminho. Na sequência seguinte, a garota, solitariamente, anda pelo terreno seco e pedregoso de Riade.

A sensação de desalento e solidão que a cena provoca é interrompida. O silêncio do deserto é quebrado por um som inicialmente tranquilo de uma música árabe. A câmera paralisa diante do olhar agora esperançoso de Wadjda que avista uma bicicleta verde correndo velozmente por cima de um muro. O ritmo da canção aumenta ao passo que se acompanha a menina correndo atrás da bicicleta que parece flanar sobre o caminhão que a carrega. No encontro com a bicicleta, instalada para venda na porta de uma loja, os olhos de Wadja exprimem incredulidade diante de seu objeto de desejo. A mão alisa o guidão enfeitado com fitas. Wadjda parece travar um diálogo silencioso, mas cheio de planos e sonhos, com a bicicleta verde. Sua 'conversa', contudo, é interrompida pelo dono da loja que lhe informa: - São 800 riais $^{4}$. É cara demais para você.

Sobre o que nos conta o filme? A impossibilidade da garota comprar uma bicicleta ultrapassa a questão financeira. Pois bem, Wadjda, conforme sugere seu contexto, é uma garota da classe média na Arábia Saudita e, portanto, não seria um grande problema para sua família despender do dinheiro para conceder-lhe seu desejo. A questão quanto a isso é a de que Wadjda é uma menina e, meninas, naquele lugar, não andam de bicicleta.

Não é que haja uma lei que as proíba disso, pelo menos não uma lei estatal devidamente formatada. Como exemplo, guardadas as devidas proporções e correndo o risco de ousar relacionar culturas e lugares tão distintos, podemos nos servir de uma comparação com algo próximo e vivido no Brasil: uma garota que quer muito comprar um boneco soldado ou uma pista para carrinhos de corrida. De certa forma, seria indevido, incomum, fora de contexto, contra os 'bons' hábitos tradicionais. Na Arábia Saudita (lá, aqui e em muitos lugares), pelo menos conforme nos conta

\footnotetext{
${ }^{4}$ Riyal é o nome da moeda saudita (no plural: riais).
} 
o longa-metragem, "desvios "desta natureza - na verdade, de qualquer natureza - têm um peso enorme contra a educação pela qual as crianças são preparadas para a vida adulta.

Voltemos ao que discutíamos: a família de Wadjda poderia comprar a bicicleta quando e se o quisesse, mas não o fazia por isso não estar de acordo com a tradição de comportamentos vinculada às meninas, com todo um longo histórico de aprendizagens que conformam a 'natureza' de corpos de crianças meninas, seus gestos, suas maneiras de ser e de conviver. Como tateando um descaminho, uma desaprendizagem que sirva de antídoto para as ideias naturalizadas que encerram a educação, a infância, o gênero, o corpo das crianças em fôrmas de ação, a protagonista vai tentar de muitos modos arrecadar a quantia necessária para a aquisição do objeto desejado e do desejo de experimentar outros modos de se fazer mulher, mesmo indo de encontro às proibições familiares e sociais. Seja pegando um pouco de dinheiro escondido da mãe, seja vendendo pulseiras no colégio, seja fazendo pequenos serviços para as colegas mais velhas, enfim, conseguir a bicicleta torna-se o grande objetivo da vida de Wadjda. Entretanto, conforme dizíamos, as proibições ligadas ao seu gênero sempre voltavam a limitá-la, a impedi-la, sob diversos níveis de punição, de agir conforme a sua vontade.

Considerando esta breve introdução sobre o cenário do filme, narraremos um caminho dividido em quatro seções, nas quais tentaremos articular pensamentos, impressões, conceitos, afetos e outras narrativas, buscando ensaiar uma escrita que pulse, bem como pulsa e se vitaliza a poesia da desaprendizagem que o corpo de Wadjda narra: afirmando-se na vida enquanto força infante.

Antes de prosseguir, talvez seja preciso dizer que entendemos gênero, infância, corpo como construções histórico-culturais e éticas (MACHADO, VASCONCELOS e MELO, 2012) e fazer três apontamentos que, sonhando com Wadjda, podem ajudar a desencaminhar modos naturalizados de fazer-pensar educação, infância, gênero e suas imagens/narrativas:

1) No interior de uma cultura, em um dado momento histórico, conformam-se formas possíveis e inteligíveis de ser crianças, que ao longo de sua educação/humanização, vão sendo identificadas como homens e mulheres de determinados modos (e não outros). Não somos crianças, não somos mulheres e homens, nos fazemos mulheres e homens pelo engajamento reiterado a normas regulatórias de gênero narradas e inscritas nos corpos. Dessa forma, a ‘simples' e tão conhecida expressão 'É um menino' ou 'É uma menina' não dá nome a uma realidade dada de antemão, mas o próprio ato de nomear instaura 
todo um processo de fazer desse corpo um corpo de homem ou de mulher. Tal nomeação é "prescritiva, e não descritiva", isto é, produz "uma invocação performativa [com] efeitos protéticos: faz corpos" (BENTO, 2006, p. 88).

2) Assim como a cultura é um campo de disputa de práticas e sentidos passíveis de serem compartilhados por um dado grupo, o corpo é "espaço de luta e de experimentação, espaço conflitivo de submissão e de subversão" (PARAÍSO, 2011, p. 149). Nessa direção, Judith Butler (2007, p. 154) afirma que a materialização dos corpos feitos por meio de normas regulatórias "nunca é totalmente completa, que os corpos não se conformam nunca completamente às normas pelas quais sua materialidade é imposta”. Os corpos são, assim, entendidos como construções histórico-culturais, mas também éticas, espaços de experimentação. Corpos se tecem encarnando normas regulatórias de gênero e de faixa etária, por exemplo, mas também (re)existem, (trans)formam-se, desfazem toda uma linearidade e fixidez dada de antemão.

3) As diferenças entre as categorias analíticas de infância e criança foram inicialmente desenvolvidas no campo da história por Philippe Ariès (1981) ao afirmar que, somente a partir da Modernidade, foi possível forjar um sentimento de infância, correspondente "[...] à consciência da particularidade infantil, essa particularidade que distingue essencialmente a criança do adulto, mesmo jovem" (ARIÈS, 1981, p. 99). Sentimento que está presente na história do Ocidente, elaborado em concomitância com mudanças de composição da família, das ideias de maternidade, paternidade e escolarização. A invenção da infância possibilitou o surgimento de uma série de tecnologias de poder com o objetivo de gerenciar a vida dos indivíduos e populações. Nesse sentido, o dispositivo de infantilidade incita a produção de saberes sobre os corpos infantis, corpos de crianças. Tal dispositivo regula relações de poder e práticas institucionais em seu nome, sob a alcunha de garantia de direitos sociais, com implicações sobre sua "saúde, alimentação, condições de existência, necessidades, interesses, desejos, identidade" (CORAZZA, 2004, p. 22).

Por outro lado, não se deve compreender, como afirma Qvortrup (2011), que a criança seja um sujeito a-histórico. Em culturas e sociedades não-ocidentais, "a ideia de infância pode não existir, ou ser formulada de outros modos. O que é ser criança, 
ou quando acaba a infância, pode ser pensado de maneira muito diversa em diferentes contextos socioculturais (COHN, 2005, p. 22). Portanto, a criança, segundo Kramer e Motta (2010), é aquela "pessoa de pouca idade", produtora e produzida pela cultura, que se constitui a partir de sua classe social, etnia, gênero, diferenças físicas, psicológicas e culturais.

Neste artigo trilhamos um caminho que não ignora o debate supracitado, mas que transita numa outra direção. Queremos nos aproximar de um outrar a infância, numa busca, não do que é, mas do que pode (vir a) ser. A infância, portanto, não como rascunho da vida adulta, mas "uma infância como intensidade, um situar-se intensivo no mundo; um sair sempre do 'seu' lugar e situar-se em outros lugares, desconhecidos, inusitados, inesperados" (KOHAN, 2010, p. 94-95). A infância como experiência limite na/da linguagem, diria Agambem (2005), que faz gaguejar nossas certezas sobre o mundo e suas lógicas. Infância não, ou pelo menos não apenas, como uma etapa cronológica da vida humana, mas como "uma condição do humano que está presente (ou pode estar presente) em diversas idades [...] essa condição que nos habita - às vezes de forma mais perceptível, às vezes quase imperceptível - desde que habitamos o mundo" (KOHAN, 2015, p. 217). Subjetividades brincantes: é a errância infantil dos nossos corpos que nos convoca essa escrita e apostamos no cinema como uma boa experimentação dessa 'sina'.

\section{CINEMA, INFÂNCIA, MARGINALIDADE E POÉTICA}

"A grandiosidade dos cineastas foi de saber criar, nas mesmas imagens, outras configurações vivíveis do pensamento" (ENGELMAN, 2005, p. 284). Assim disse Selda Engelman, baseando-se em Deleuze, para comentar o cinema produzido no pósguerra. No mesmo trilho deste pensamento, Alain Badiou $(2015$, p. 31$)$ afirma que o cinema "é a criação de novas ideias sobre o que é a ideia" e, assim como a filosofia, empreende esforços na invenção de novas sínteses sobre os acontecimentos, rupturas acerca das arbitrariedades da vida e do vivido.

As questões expressas nestas sentenças são pistas para criarmos um caminho a se seguir, pensando cinema e infância. Outras configurações vivíveis: conversar com um cinema que, subvertendo imagens-clichês, proponha, infantilmente, outros territórios existenciais. Estabelecer um diálogo encarnado entre o que estamos sendo e os apontamentos inquietantes para viveres outros. Não só "outras configurações", 
mas reconfigurações, ou ainda mais, destruições, rompimentos, nascimentos de novidades, subjetividades insurgentes. Detemos, portanto, ao menos o que nos parece uma grande pista para este nosso (des)caminho que se inicia: cinema e infância se cruzam na inventividade.

Mas o que é criar? Se dirá, por certo, que criar é "dar existência a". Portanto, o ato da criação significa dar existência a algo, e esse algo, logicamente, não existia num passado anterior ao próprio ato que o concebeu. Sendo assim, a sua condição neste passado era a de inexistência. Ora, parece evidente que falar sobre algo, ou mesmo descrevê-lo quando esse algo não existe, é uma tarefa impossível. Isso porque não nos foi dado nenhum elemento sobre o objeto para que se possa dizê-lo. E como se faz possível a criação, já que não existiam elementos próprios do objeto criado num momento que lhe foi anterior? Esta é a grande questão do ato de criar e a marca de sua grandeza: a criação se dá na realização de algo a partir de um uso completamente novo dos elementos que compunham outros objetos. Isso é dizer que criar pressupõe trazer à realidade algo que outrora fora impossível de se conceber. Aí está também seu absurdo. Como se faz algo que, até antes do momento mesmo de sua concepção, era impossível? Esta questão não tem, absolutamente, uma única resposta. O que se pode dizer, ainda que de forma rudimentar, é que a criação provavelmente está relacionada com um movimento muito próprio da vida, que é o de se (re)inventar por meio da experiência, nos termos apontados acima (FOUCAULT, 2010).

Portanto, a mudança que a criação traz consigo pode ter a ver com as trajetórias que a vida traça para si mesma, com a constante atualização que parece ser uma de suas fundamentais características (a de não ter fundamento) e desrazoável razão da continuidade de sua existência. Nessa direção, em mu-dança, esse texto agencia-se com o pensador romeno Emil Cioran (2012), na medida em que se tece afetado por sua definição para o ato de criar: "Criar significa salvar-se provisoriamente das garras da morte" (p. 21).

A definição de criação convocou a ideia de marginalidade articulada à de poética. Esta nos chegou com o auxílio do monge católico Thomas Merton, quando perguntado sobre a relevância de alguns personagens marginais, no marcante ano de 1968:

Monges e hippies e poetas são relevantes? Não, somos deliberadamente irrelevantes. Vivemos na arraigada irrelevância que é própria de cada ser humano. Quem está à margem aceita a irrelevância básica da condição humana, uma irrelevância manifesta sobretudo pela existência da morte. Quem está à margem, o monge, o desalojado, o prisioneiro, 
todas essas pessoas vivem na presença da morte, o que coloca em questão o sentido da vida. Ele [aquele que se põe à margem] luta contra sua própria mortalidade, tentando buscar algo mais profundo que a morte; e o ofício do monge ou daquele que está à margem, o meditativo ou o poeta, é ir além da morte ainda nesta vida, ir além da dicotomia entre vida e morte, e ser, por isso mesmo, testemunha da vida (MERTON, 1968, apud BINGEMER, PINHEIRO, 2016, p. 391).

Mas o que seria "ir além da dicotomia entre vida e morte"? O que é, portanto, "ir além"? O que Merton parece apontar, principalmente quando diz que, indo além desta dicotomia, somos "testemunhas da vida", é que este "ir além" tem a ver com nossa capacidade vital de invenção, de olhar para o que ainda não é. A inventividade, neste caso, adotando invenção como sinônimo de criação, é a faculdade que nos permite distanciar-nos momentaneamente da vida, pelo menos conforme ela nos está dada, e de seu direcionamento iminente para a morte, para produzir sobre a realidade uma nova forma imanente.

Afinal, o que é criar? Dar existência a algo, uma forma qualquer que não existia no passado e, ao mesmo tempo, salvar-se provisoriamente das garras da morte. Não é mesmo isso que é testemunhar a vida? Testemunhar esse movimento que a caracteriza? Reinventando-nos, criando, existimos vivamente. Nesta marginalidade, que é, portanto, estar constantemente no limiar entre vida e morte, existência e extinção, cultivamos a faculdade absurda de trazer ao mundo uma nova forma de viver e para viver. Testemunhamos, aí, a capacidade fantástica de rearticulação da vida.

Parece-nos que é neste sentido que Jorge Larrosa (2006a), valendo-se do pensamento de Hannah Arendt, afirma que infância tem a ver com nascimento. Assim, aos personagens citados por Thomas Merton, o monge, o hippie e o poeta, adicionaríamos mais um: o infante. Mia Couto, na orelha do livro "A diaba e sua filha" escrito por Marie NDiaye (2011), usando um provérbio moçambicano, pode nos ajudar. Lá ele diz que "a vida de cada um é como um rio", em que o tempo (atual) que nos cabe para viver seria alimentado por uma fonte eterna: a infância. Assim pensada, a infância não seria um tempo passado (muitas vezes a assombrar e restringir nossos desenvolvimentos futuros pelas marcas afetivas, cognitivas e sociais ali inscritas). Ela seria sim essa capacidade humana infinita de nos renovarmos entre nascente e estuário, uma travessia feita pela arte de (des)aprender, de inventar.

Qual pode ser, pois, a poética marginal (infantil) do cinema? Como possibilidade de nos aliarmos a esta infância "como figura do porvir, da abertura, do salto, do que não se sabe" (LARROSA, 2006b, p. 63), o cinema, ou alguns tipos 
de cinema, nos ensinam a olhá-la a partir de suas lentes, menos numa necessidade de capturá-la e mais de percebê-la em sua alteridade. Trata-se de "desnaturalizar o olhar, de liberar os olhos, de aprender a olhar com olhos de criança". (TEIXEIRA, LARROSA, LOPES, 2006, p. 16) e, deste modo, estranhar o que está dado diante de nós e em nós, petrificado como mesmidade (mesma-idade). Eis a grande dificuldade de olhar, pensar e sentir uma infância que nos supera como possibilidade.

O que talvez importe nesse encontro com Wadjda (personagem) e Haiffa (diretora) não é o que se é capaz de falar sobre "o outro", mas o falar com "ele". Ou talvez fosse mais interessante dizer: nos agenciando com Wadjda e Haiffa, experimentamos um devir-criança e um devir-mulher, em que não importam mais as fronteiras entre eu (europeu, homem da razão, masculino, adulto) e outro (crianças, mulheres, poetas, povos primitivos), mas o espaço do entre, prenhe de vida.

Portanto, como Deleuze (2013) ao pensar o cinema e as imagens em Godard, com "O sonho de Wadjda" procuramos, guiados pelas mãos da menina (criança) e pelo olhar da diretora (mulher), gaguejar a infância e o gênero, deixando para trás as certezas encarnadas em nossos corpos e, na procura não por "imagens justas", mas por "justo imagens" que avessem a infância e o gênero, nos atentar para aquilo que deles não vemos/conhecemos ou que insistimos em não ver/conhecer.

Assim parece ser possível relacionar infância, poética e cinema. Isso na medida em que infância e poética têm a ver com criar no sentido mais extremo, que é o de realizar o que era impossível. Neste texto, esses dois conceitos estão de tal forma relacionados que, falando de um estaremos, quase certamente, falando do outro.

Tentaremos explicar, começando pela ideia de poética: é o viver inventivo, o viver que corresponde àquele limiar, àquela marginalidade de quem, nos cumes da vida, cria caminhos por onde a própria vida pode fluir. A poética, portanto, é viver aberturas que possibilitem a emergência do novo. É viver - capitulando tudo o que se pode descrever sobre isso - poeticamente. O estado de criação ganha um nome especial: o estado lírico. Nas palavras de Cioran (2012):

O estado lírico é um estado que transcende formas e sistemas. É uma fluidez, uma corrente interior que funde, num só impulso, como numa convergência ideal, todos os elementos da vida interior, produzindo um ritmo pleno e intenso. Diante do refinamento de uma cultura aprisionada em formas e limites que mascaram tudo, o lirismo é uma expressão bárbara. Eis de fato o seu valor, o de ser bárbaro, ou seja, de ser só sangue, sinceridade e chamas (p. 19). 
Portanto, como um estado que "transcende formas e sistemas", ou talvez fosse melhor dizer, que tem a potência de desnaturalizar de forma imanente a transcendência das formas e sistemas, o estado lírico, próprio da vida poética, é uma fluidez de forças que se fazem um grandioso "apetite de vida", ou como nos diz, em poesia, Manuel Bandeira (1955), “O furor da criação dionisíaco estua / No fundo das rechãs, no flanco das montanhas, / E eu observo-o nos sons, na glória da luz crua / E ouço-o ardente bater dentro em minhas entranhas". É um poder que faz da vida uma experiência extrema de vitalidade, um campo próprio para o que jamais, antes, pôde existir: "Tenho êxtases de santo... Ânsias para a virtude... / Canta em minhalma absorta um mundo de harmonias. / Vêm-me audácias de herói... Sonho o que jamais pude / - Belo como Davi, forte como Golias..."(BANDEIRA, 1955, p. 48).

E a infância, como diferenciá-la? As imagens fílmicas de Mansour não deixam vasar um grande furor infantil? Como diferir do que, por meio da educação, tem se tentado: aprisionar corpos de crianças, vampirizar seu furor vivente para torná-las, se não corpos dóceis, corpos empreendedores de si, ração do capital? Foi Walter Kohan (2009) quem disse, sobre encontrar uma infância para si, que ela é "instaurar novos lugares no mundo, encontrar o que o mundo tem de novo, inventar um novo mundo, encontrar-se em um outro mundo, singular" (KOHAN, 2009, p. 332). Infância como criação de um mundo provisório. Ela é a força que cria, mas, mais ainda, é também a que reconhece a necessidade de se criar. A força que, na exaustão de certas formas, movimenta, inventa outras. Infância como intensidade, outro tempo que não o cronológico, infância como duração.

A infância é devir; sem pacto, sem falta, sem fim, sem captura; ela é desequilíbrio; busca; novos territórios; nomadismo; encontro; multiplicidade em processo, diferença, experiência. Diferença não-numérica; diferença em si mesma; diferença livre de pressupostos. Vida experimentada; expressão de vida; vida em movimento; vida em experiência. (KOHAN, 2009, p. 332)

Nessa beleza fabuladora que caracteriza esta força infantil, encontramo-nos com a reflexão de Nietzsche que, sozinha, tomou para si os três conceitos com os quais nos propusemos a conversar:

Assim como não apenas a idade adulta, mas também a juventude e a infância têm valor em si, não devendo ser estimadas tão-só como pontes e passagens, do mesmo modo têm seu valor os pensamentos inacabados. Por isso não devemos atormentar um poeta com uma sutil exegese, mas alegrarmo-nos com a incerteza de seu horizonte, 
como se o caminho para vários pensamentos ainda estivesse aberto. Estamos no limiar; esperamos, como a desenterrar um tesouro: como se estivesse para ocorrer um profundo achado. $\mathrm{O}$ poeta antecipa algo do prazer do pensador, quando este encontra um pensamento capital, e assim nos faz tão ávidos que procuramos apanhá-lo; mas ele passa volteando por nossa cabeça, mostrando suas belíssimas asas de borboleta - e contudo nos escapa (NIETZSCHE, 2005, p. 129).

Infância, poética e marginalidade, entendidas desse modo, cruzam-se como forças que permitem, em nós, a criação. Ao mesmo tempo, são forças produtoras de formas "inacabadas". Forças que, em vez de desenharem a cria perfeita e eterna que virá ao mundo para ficar como é ou para ser o que se espera que seja (o adulto ideal), concebem sempre embriões provisórios que, em seus pedaços que "faltam", comportam a virtualidade do possível e, mais ainda, daquilo que não podemos jamais captar, pois ela passa "volteando por nossa cabeça" e, apesar de mostrar suas "belíssimas asas de borboleta", devemos contentar-nos com apenas o vislumbre de seu futuro porque, contudo, ele "nos escapa".

\section{INFÂNCIA, CINEMA E LIRISMO ABSOLUTO: POR UMA EDUCAÇÃO INVENTIVA ${ }^{5}$}

"Assim como o adulto, a criança vê portas em tudo que se vivencia e se aprende: mas para ela são acessos, para ele, apenas passagens" (NIETZSCHE, 2005, p. 122). Daí se faz o lirismo infantil: ver mais acessos que passagens. Ora, o que é a passagem? A transição, o atravessamento de um lugar para um outro lugar. Outro lugar, entretanto, já conhecido, esperado, programado ou simplesmente desejado. Já o acesso não, ele é uma chegada. Mas um chegar onde? Em algum lugar. Contudo, um novo lugar. Um espaço que talvez não se imaginasse chegar. Por isso o acesso é mais resultado de um descaminho do que de um caminho, trajetória pensada e planejada previamente. Ele não é apenas uma surpresa, mas uma vitória, uma conquista: "ainda que provisório, é meu próprio caminho". E é essa pequena realização, demonstração da vontade pela vitalidade do novo, que faz do infante um andarilho, nômade e estrangeiro descobridor de caminhos:

[...] a etimologia pode nos ajudar outra vez: a "experiência" porta consigo a mesma raiz de percurso e de perigo, uma raiz "per" ligada a um deslocamento, a uma viagem, a uma translação, que não antecipa o ponto de chegada... assim, pensar é deslocar-se, deixar uma terra,

${ }^{5}$ Inspirando-nos em Kastrup (2009). 
habitar outra, trasladar-se ao estrangeiro.... tentamos sugerir que, para isso, pode ser vital situar a ignorância em um lugar afirmativo. O pensamento encontra força na ignorância. Também na infância. (KOHAN, 2009, p.337)

Como contraponto, pensemos com imagens fílmicas da escola na qual estuda, no filme, Wadjda. Este foi o espaço a partir do qual a trama pôde mostrar o encontro de muitas forças que dizem respeito à forma como alguns tipos de corpos são educados para determinadas funções. Dentro da escola, a educação religiosa, moral, materializou-se na figura da diretora. Esta figura é importante neste sentido, no de materializar as forças responsáveis por realizar a função de educar para. Exatamente isso, uma educação para uma direção.

Uma educação que seja um veículo de passagem e não de acesso; não um rito propriamente dito, mas algo mais continuado, mais demorado, mais dolorido. Um veículo que leve o mais diretamente possível para um lugar esperado. E para tanto, uma educação que se queira de tal forma precisa, prescritiva, que se queira como um caminho único e o mais reto possível, deve trazer consigo armas poderosas o suficiente para conter as possibilidades de desvios. E aí retornamos à diretora. Líder de um colégio religioso cujo grande objetivo é afirmar não somente uma tradição, mas um destino. É transmitir não somente uma história e seus afetos, mas encaminhar o futuro.

Primeiro são pés. Pés que balançam e se movimentam em conformidade com a música. Um coral de vozes infantis é o que se ouve, mas o que se vê são seus pés: calçados em meias brancas além de sapatos formais e pretos, uniformes. A canção versa junto às vozes: - Entreguei-me a Deus, creio que há um lugar para mim. No céu eterno, entre mártires e puros sempre estarei. Levantei meu coração com a luz da fé, e minha paciência. Quando estiver perdida, guie-me pelo caminho correto. Pelo caminho correto. Guia-me e faz de meus acessos, passagens.

- Parem! - Diz a professora ao coral - Aos seus lugares! Vamos tentar novamente.

Duas garotas passam ao longe e olham para as meninas em formação. Encontram os olhos de uma em especial. Esta lhes responde, portanto, com um pequeno aceno e um sorriso, desviando-se do exercício. Eis que a professora flagra o desvio e produz a correção.

- Wadjda!! (Silêncio entre as meninas)

- Aproxime-se.

Eis que vemos novamente os pés. Desta vez, porém, afastam-se aqueles uniformes/formatados e surge um pé diferente. Um pé estrangeiro. Um pé cujo caminho 
se faz de acessos. (A professora desliga o som que servia de referência para o exercício). Mas, o que diz a canção? "Quando estiver perdida, / Guie-me pelo caminho correto."

- Repita os primeiros versos. - Ordena a professora à menina que se aproximara.

A garota Wadjda permanece silenciosa.

- Não quer que escutemos sua voz?

Irredutível, Wadjda permanece calada.

- Saia. Saia! - É o que, para a professora, resta a dizer diante daquela postura.

À diretora e professoras cabe policiar o comportamento das alunas conforme os critérios que garantam seus objetivos. Então, se estão se pintando às escondidas, se estão chegando sem cobrir o rosto, se estão trazendo cordõezinhos com cores nacionais ou de times, se estão falando mais alto do que as mulheres deveriam, se estão possivelmente - sendo vistas por homens e por mulheres que se querem mulheres apenas em uma determinada direção, se estão, por fim, descaminhando o caminho previsto, faz-se necessária alguma intervenção. Esse é, sem dúvidas, o papel mais visível que a diretora exerce. Entretanto, existe um algo mais. Foi ela mesma quem disse para Wadjda: "Você não vai acreditar, mas você era como eu, na sua idade. E veja agora!". O que se quer marcar com isso? Algumas possibilidades: 1) suas tentativas de desvio não vão resultar em nada, você acabará, querendo ou não, cedendo; 2) eu já estive no seu lugar e sei o que se passa aí dentro, por isso mesmo eu posso dizer que tenho como dirigi-la de volta ao rumo, bem como aconteceu comigo (não se preocupe, isso vai passar); 3) eu sou a marca da extinção de sua vontade de desvio. Esse é o objetivo de meu programa.

Desta forma, a diretora está marcando a dimensão do poder. Ela conhece o desvio, ela sabe das forças que o motivam e, mais do que isso, sabe como repará-lo e extingui-lo. Ela se faz como um "terror totalitário [que] poderá identificar-se, então, com a redução e, no limite, com a destruição da novidade inscrita no nascimento e com a correspondente pretensão de escrever de maneira antecipada a história" (LARROSA, 2006a, p. 4). Ela não somente é a materialização das formas instituídas que pretendem conformar as meninas, mas ela é a confirmação encarnada de que estas mesmas formas são eficazes - pelo menos ao que parece, pois ela mesma traz consigo seus casos misteriosos... (como a entrada do ladrão-amante em seu quarto durante a noite).

Fora da escola as marcas desta educação concentram-se na figura da mãe de Wadjda. Entretanto, ela não é de forma nenhuma uma policial, alguém que, 
como a diretora, buscaria fiscalizar o comportamento da garota em busca das suas possíveis transgressões. Esta mãe será a figura que caracterizará a falência, a dor e a solidão deste tipo de vida feminina transmitida pelo filme. Sendo assim, ao mesmo tempo em que ela tenta afirmar o valor e a força da tradição em suas ações, não agindo quase nunca em contradição ao que se espera de uma mulher casada, ela se depara o tempo inteiro com situações que a desestabilizam.

Seu marido permanece fora durante semanas. Mais tarde descobrimos que ele e sua mãe estão planejando seu segundo casamento. Sim, e isso causa imensa dor na mãe de Wadjda. Além de não querer, afinal, dividir seu marido com outra esposa, ela sente muito a razão deste possível evento: ela não pode mais conceber uma criança, e seu marido quer ter um filho homem. Isso a fere demais. É como se a própria tradição, parte tão fundamental de sua vida, estivesse lhe punindo por uma questão completamente fora de seu controle. Afinal, tentar conceber mais um filho poderia implicar em sua morte. A figura da mãe de Wadjda é a demonstração da perversidade que pode haver dentro do próprio jogo da tradição. Desta forma, por não poder participar deste jogo do jeito que lhe era esperado, ela é colocada numa margem ainda mais "exterior" do que a que já cabe às mulheres em geral, como se houvesse se tornado ainda mais limitada em seu já estreito território existencial 'feminino'. Mas Wadja, à margem, insiste em reexistir...

Viver poeticamente, inventivamente, infantilmente, em constantes estados líricos: esse é o lirismo absoluto da infância. A criança, movida grandemente pelas forças infantis, carrega em si, quase como uma condição de existência, uma faculdade aflorada de atualizar os espaços do mundo através de suas expressões. E com isso, ela parece ter em suas mãos um poder inesgotável. "A criança olha / Para o céu azul. / Levanta a mãozinha, / Quer tocar o céu". Mas será que ela pode? "Não sente a criança/ Que o céu é ilusão: / Crê que o não alcança, / Quando o tem na mão" (BANDEIRA, 1955, p. 338).

E não é mesmo a criança um profeta infantil? Traz em suas mãos o céu e, no instante posterior, as boas novas. O infante é este quase-profeta, cujas mãos, banhadas de céu, escondem o impossível. A cada passo, entretanto, poderá acessar mais uma novidade. E a humanidade se encanta diante da beleza daquela velha estrela-guia que, errante, não cansa de nos desviar dos caminhos, mas que, nos desvios mesmos, vitalizanos em novas chegadas. Portando uma infância desesperada, Cioran nos mostra do que se trata, afinal, esse lirismo absoluto que, escondido talvez nos confins de nosso espírito - ou no limite mais exterior de nossa epiderme -, jamais nos abandona: 
No lirismo absoluto, a expressão se confunde com a realidade, torna-se tudo, torna-se um aspecto do ser. Ela cessa de ser uma objetivação parcial, menor e não reveladora, para se tornar parte de nós. Aí não têm mais importância só a sensibilidade ou a inteligência, mas todo o ser, todo o corpo, toda a nossa vida, com seus ritmos e pulsações. [...] Esse lirismo jamais assumirá formas em expressões separadas, mas cada expressão é uma parte de nós (CIORAN, 2012, p. 71).

Mas o verdadeiramente intrigante é como esse lirismo absoluto, ou seja, a liberdade com a qual deixamos de separar nosso corpo e nossa vida das nossas obras, realizações e expressões, é tão facilmente observado num breve contato com uma criança. Ela é um ser tão completo em sua enorme abertura para a virtualidade, que o mundo inteiro ao seu redor parece se refazer diante de suas brincadeiras. Como uma brincadeira mesmo, o mundo se modifica, altera ou perde suas funções, troca os papéis, os lugares, os signos. São passos, todos esses movimentos. Passos de uma verdadeira (mu)dança ritmada por uma força pulsante em seu absoluto lirismo: a infância.

\section{UMA ÚLTIMA NOTA}

Encaminhando-nos para uma finalização do texto, retomemos a protagonista Wadjda. Ela parece ser a marca de uma ironia. Tê-la como personagem principal foi muito marcante durante o desenvolvimento do filme, porque, a partir de sua perspectiva, se consegue não só identificar os vetores pelos quais as meninas são encaminhadas e educadas para a vida em seus moldes tradicionais, mas acompanhar de perto como alguém, com ações tão míseras, pode produzir desvios tão fundamentais nas estruturas. E ainda mais impressionante: produzir desvios através de um uso muito próprio destas mesmas estruturas.

Percebamos que grande ironia, por exemplo, quando, através do concurso escolar sobre o Corão, ou seja, através de pelo menos duas forças que a tentavam direcionar - a religiosa e a escolar - Wadjda buscou arrecadar o dinheiro necessário para comprar a sua bicicleta, atitude negada por estas mesmas duas instituições! Nesta lógica, a personagem foi subvertendo o funcionamento das engrenagens tradicionais e criando novos espaços a partir dos quais poderia ensaiar outros desenlaces / outras desembocaduras para seu caminho. Wadja foi mesmo uma grande união, enquanto sujeito marginal, de três características muito interessantes: ironia, oportunismo e cinismo. Articulando essas três características, ela se empoderou diante de quase todas as adversidades que emergiam, subvertendo-as. 
Oportunismo para conseguir dinheiro através de seus trabalhos desviantes, utilizando-se até mesmo dos símbolos máximos de sua cultura; cinismo para não se deixar enquadrar no lugar da culpada, para passar distante de qualquer culpa de ordem moral; ironia para, conseguindo o que pretendia através do uso performático do papel que gostariam de impô-la, dizer abertamente à figura da ordem e disciplina quais eram suas intenções. Esta é uma forma marginal de se viver, forma que produz sobre o real várias subversões e que possibilita ao ser que a exercita uma ampliação dos territórios para o seguimento de seus caminhos. Wadjda, uma criança-peste, pestinha, cabeça dura, não pôde ser contida. Essa é sua grande marca. Por ser infante, poeta marginal, utilizou-se desta marginalidade para desengonçar as normas que a marginalizam e produzir uma nova realidade. É essa a sua poética, a da infante que traz consigo o poder da subversão que produz novidade e que, apesar de todas as forças conservadoras que a envolvem, as escapa.

\section{REFERÊNCIAS}

AGAMBEN, G. Infância e história: destruição da experiência e origem história. Belo Horizonte: Editora UFMG, 2005.

ARIÈS, Philippe. História Social da Criança e da Família. São Paulo: LTC, 1981.

AUTORIDADE da Arábia Saudita diz que cinemas e shows são prejudiciais. Folha de São Paulo. Ilustrada. Disponível em: http://www1.folha.uol.com.br/ilustrada/2017/01/ 1850077-autoridade-da-arabia-saudita-diz-que-cinemas-e-shows-sao-prejudiciais.shtml. Acesso em 31/01/2017

BADIOU, Alain. O cinema como experimentação filosófica. In: YOEL, Gerardo. Pensar o cinema: imagem, ética e filosofia. São Paulo: Cosac Naify, 2015, p. 31-82.

BANDEIRA. Manuel. Poesias: 7. ed. Rio de Janeiro: José Olympio, 1955.

BADIOU, Alain. O cinema como experimentação filosófica. In. YOEL, Gerardo. Pensar o cinema: imagem, ética e filosofia. São Paulo: Cosac Naify, 2015, p. 31-83.

BALESTRIN, Patrícia Abel; SOARES, Rosângela. "Etnografia de tela": uma proposta metodológica. In: MEYER, Dagmar Estermann; PARAÍSO, Marlucy Alves. Metodologias de pesquisas pós-críticas na educação. Belo Horizonte: Mazza Edições, 2012, p. 87-110.

BARROS, Manoel de. Livro sobre Nada. Rio de Janeiro: Record, 1997.

BERGALA, Alain. O cinema epifânico e o sagrado de André Bazin. In: BAZIN, André. O realismo impossível. Belo Horizonte: Autêntica Editora, 2016, p. 199-214.

BINGEMER, Maria Clara; PINHEIRO, Marcus Reis (Org.). Narrativas Místicas: Antologia de textos místicos da história do cristianismo. São Paulo: Paulus, 2016.

BUTLER, Judith. Corpos que pesam: sobre os limites discursivos do "sexo". In: LOURO, G. L. (org.). O corpo educado: pedagogias da sexualidade. Belo Horizonte, Autêntica, 2007.

CIORAN, Emil. Nos cumes do desespero. São Paulo: Hedra, 2012. 
COHN, Clarice. Antropologia da criança. Rio de Janeiro: Zahar, 2005.

CORAZZA, Sandra Mara. História da infância sem fim. Ijuí: Editora Unijuí, 2004.

DELEUZE, Gilles. Três questões sobre seis vezes dois (Godard). In:

Conversações. São Paulo: Editora 34, 2013, p. 53-63.

DIRECTOR'S Cut: Wadjda | Haifaa Al Mansour. S.i.: World Economic Forum, 2015. P\&B. Disponível em: https://www.youtube.com/watch?v=q3q05VLc6u4. Acesso em: 27 jan. 2017.

ENGELMAN, Selma. Imagens de um cinema da imanência. In: Daniel Lins. (Org.) Nietzsche Deleuze - Imagem, Literatura, Educação. Rio de Janeiro, 2005, v. , p. 276-287.

FELDMAN, Núria Aidelman; APARÍCIO, Laia Colell. Filmar uma criança: a construção de um espaço comum. In: TEIXEIRA, Inês Assunção de Castro; LARROSA, Jorge; LOPES, José Miguel. A infância vai ao cinema. Belo Horizonte: Autêntica, 2006, p. 131-142.

FISCHER, Rosa. Cinema e pedagogia: uma experiência de formação ético-estética. Revista Percursos, Florianópolis, v. 12, n. 01, p. 139-152, jan./jun. 2011

FOUCAULT, Michel. Conversa com Michel Foucault. In: Repensar a política. Ditos \& Escritos VI. 1a. ed. Rio de Janeiro: Forense, 2010.

FOUCAULT, Michel. Polêmica, política e problematizações. In: Ditos \& Escritos V: Ética, sexualidade, política. Rio de Janeiro: Forense Universitária, 2006.

HIKIJI, Rose S. G. Antropólogos vão ao cinema - observações sobre a constituição do filme como campo. Cadernos de Campo, São Paulo, v. 7, p. 91-113, 1998.

KASTRUP, Virgínia. O funcionamento da atenção no trabalho do cartógrafo. In: PASSOS, E.; KASTRUP, V.; ESCÓSSIA, L. (org.). Pistas do método da cartografia: pesquisa-intervenção e produção de subjetividade. Porto Alegre: Sulina, 2009. p. 32-51.

KOHAN, Walter Omar. Infância e Filosofia. In: SARMENTO, Manuel; GOUVEA, Maria Cristina Soares. Estudos da infância: educação e práticas sociais. Petrópolis: Vozes, 2009, p. 40-61.

KOHAN, Walter Omar. Devir-criança na filosofia: infância da educação. Belo Horizonte: Autêntica, 2010, p. 55-62.

KOHAN, Walter Omar. Visões de filosofia: infância. Alea, Rio de Janeiro , v. 17, n. 2, p. 216-226, Dec. 2015.

KRAMER, S.; MOTTA, F.M.N. Criança. In: OLIVEIRA, D.A.; DUARTE, A.M.C.; VIEIRA, L.M.F. Dicionário: trabalho, profissão e condição docente. Belo Horizonte: UFMG/Faculdade de Educação, 2010. CDROM. Disponível em: http://www.gestrado. net.br/?pg=dicionario-verbetes\&id=107. Acesso em 11 de junho de 2018.

LARROSA, Jorge. O enigma da infância. In: Pegadogia Profana: danças, piruetas e mascarados. Belo Horizonte: Autêntica, 2006a, p. 183-198.

LARROSA, Jorge. As crianças e as fronteiras: várias notas a propósito de três filmes de Angelopoulos e uma coda sobre três filmes iranianos. In: TEIXEIRA, Inês Assunção de Castro; LARROSA, Jorge; LOPES, José Miguel. A infância vai ao cinema. Belo Horizonte: Autêntica, 2006b, p. 51-73.

LARROSA, Jorge. Tremores: escritos sobre a experiência. Belo Horizonte: Autêntica, 2016.

LOURAU, Renè. A análise institucional. Petrópolis, Vozes, 1995.

LOURO, Guacira L. Pedagogias da sexualidade. In: O corpo educado: pedagogias da sexualidade. Belo Horizonte, Autêntica Editora, 2007, pp.7-34. 
MACHADO, Dagoberto; VASCONCELOS, Michele; MELO, Aldo. O corpo como fio condutor para a ampliação da clínica. Polis e Psique, Vol. 2, Número Temático, 2012, pp. 147-170.

MARCELLO, Fabiana de Amorim. Cinema e educação: da criança que nos convoca à imagem que nos afronta. Revista Brasileira de Educação, v. 13, p. 343-356, 2008

MARCELLO, Fabiana de Amorim. Quando o cinema vê a criança pelo avesso. In: DORNELLES, Leni Vieira; BUJES, Maria Isabel Edelweiss (org.). Educação e infância na era da informação. Porto Alegre: Editora Mediação, 2012, p. 131-160.

QVORTRUP, Jens. Nove teses sobre a "infância como um fenômeno social". Pro-Posições, Campinas, v. 22, n. 1, p. 199-211, abr. 2011.

NDIAYE, Marie. A diaba e sua filha. São Paulo: Cosac Naify, 2011.

NIETZSCHE, Friedrich. Humano, Demasiado Humano (tradução de Paulo Cezar de Souza). São Paulo: Companhia das Letras, 2000.

NIETZSCHE, Friedrich. Humano, Demasiado Humano II. São Paulo: Companhia das Letras, 2008.

O SONHO de Wadja. Direção: Haiffa Al Mansour. [S.I.]: Imovision, 2012, 1 DVD (98 min.).

POLAYNE, Patrícia. Arrastada. Intérpretes: Patrícia Polayne. O Circo Singular, 2009. $1 \mathrm{CD}$.

PARAISO, Marluci. Raciocínios generificados no currículo escolar e possibilidades de aprender. In: LEITE, C. et al. (org.). Políticas, fundamentos e práticas do currículo. Porto, Porto Editora, 2011.

PAULON, Simone. A desinstitucionalização como transvaloração. Apontamentos para uma terapêutica ao niilismo. Athenea, n. 10, p. 121-136, 2006.

PELBART, P. P. Vida capital: ensaios de biopolítica. São Paulo: Iluminuras, 2003.

PRADO Jr., Plínio. O suplício da infância: notas sobre Bergman e a condição de infans.

ROCHA, Firmino. O Canto do dia Nôvo. Salvador: Mensageiro da Fé, 1968.

ROLNIK, S. Toxicômanos de identidade: subjetividade em tempo de globalização. In: LINS, D. (org.). Cultura e subjetividade: saberes nômades. Campinas: Papirus, 1997. p. 19-24.

TEIXEIRA, Inês A. de Castro; LARROSA, Jorge; LOPES, José Miguel. Olhar a infância. In: A infância vai ao cinema. Belo Horizonte: Autêntica, 2006, p. 11-28. 